\title{
Kualitas komunikasi dan kepuasan pasien dalam pelayanan radiografi kedokteran gigi RSGM Prof. Soedomo
}

\author{
Kartika Simatupang*, Isti Rahayu Suryani ${ }^{* *}$, Rini Widyaningrum**, Rosa Amalia*** \\ *Program Studi Higiene Gigi, Fakultas Kedokteran Gigi, Universitas Gadjah Mada, Yogyakarta, Indonesia \\ **Departemen Radiologi Dentomaksilofasial, Fakultas Kedokteran Gigi, Universitas Gadjah Mada, Yogyakarta, Indonesia \\ ${ }^{* * *}$ Departemen IImu Kedokteran Gigi Pencegahan dan IImu Kesehatan Gigi Masyarakat, Fakultas Kedokteran Gigi, \\ Universitas Gadjah Mada, Yogyakarta, Indonesia \\ JI Denta No 1, Sekip Utara, Yogyakarta, Indonesia; e-mail: ssimatupangkartika@gmail.com
}

Submisi: 26 September 2016; Penerimaan: 11 Oktober 2016; Publikasi online: 28 April 2017

\begin{abstract}
ABSTRAK
Kualitas komunikasi merupakan salah satu komponen yang penting pada layanan kesehatan karena berhubungan dengan kepuasan pasien. Penelitian ini bertujuan untuk mengetahui hubungan antara kualitas komunikasi pada pelayanan radiografi kedokteran gigi dengan tingkat kepuasan pasien Rumah Sakit Gigi dan Mulut Prof. Soedomo Universitas Gadjah Mada. Penelitian ini dilakukan pada 100 responden terpilih. Kuesioner pada penelitian terdiri dari kuesioner kualitas komunikasi yang terdiri dari 19 butir pertanyaan yang mencakup 4 aspek penilaian komunikasi (introduce, explanation, listen carefully, dan empathy) dan kuesioner tingkat kepuasan pasien yang terdiri dari 20 butir pertanyaan yang mencakup 4 aspek penilaian kepuasan (open-endedness, empathy, abilities, dan general satisfaction). Skor hasil kuesioner penelitian diukur menggunakan skala likert dan penetapan kategori penilaian diukur menggunakan penilaian acuan patokan. Hasil uji korelasi Spearman menunjukkan hubungan yang bermakna $(p<0,05)$ antara kualitas komunikasi dengan tingkat kepuasan pasien, dengan arah korelasi positif dan kekuatan korelasi sangat kuat $(r=0,856)$. Penilaian pasien terhadap kualitas komunikasi radiografer sebagian besar menunjukkan kategori baik (64\%). Aspek komunikasi yang paling berpengaruh adalah empathy $(r=0,842)$ dan introduce $(r=0,752)$. Sebagian besar pasien memberikan penilaian kepuasan pada tingkat puas $(71 \%)$, dengan aspek penilaian kepuasan yang paling berpengaruh adalah $(r=0,807)$ dan general satisfaction $(r=0,706)$. Semakin baik komunikasi yang digunakan oleh radiografer maka akan semakin tinggi pula tingkat kepuasan pasien terhadap pelayanan radiografi kedokteran gigi Rumah Sakit Gigi dan Mulut Prof. Soedomo Universitas Gadjah Mada.
\end{abstract}

Kata kunci: kepuasan pasien; kualitas komunikasi; kuesioner; radiologi kedokteran gigi

ABSTRACT: The quality of communication and patient satisfaction in dental radiography. The quality of communication is one of important components in health service. The aim of this study is determine the relationship between the quality of communication and the level of patients in dental radiography service at Prof. Soedomo Dental Hospital Faculty of Dentistry Universitas Gadjah Mada. This study was conducted on 100 selected respondents. The quality of communication questionnaire consisted of 19 questions involving 4 aspects of communication assessment (introduction, explanation, careful listening, and empathy) and patient satisfaction questionnaires with 20 questions involving 4 aspects of satisfaction assessment (open-endedness, empathy, abilities, and general satisfaction). The score results of the questionnaire were measured by a Likert scale and the category of the assessment was based on criterionreferenced interpretation. Spearman correlation test showed that a significant relationship $(p<0.05)$ between the quality of communication and the level of patient satisfaction with the positive direction of correlation and the strong correlation ( $r$ $=0.856)$. Patient assessment for the quality of radiographer communication mostly showed good category (64\%) with the most influential communications aspect found in empathy $(r=0.842)$ and introduction $(r=0.752)$. The level of satisfaction assessment by the majority of patients was satisfied $(71 \%)$ with the most influential satisfaction aspect found in empathy $(r=0.807)$ and general satisfaction $(r=0.706)$. The better communication used by the radiographer could lead to the higher the level of patient satisfaction in dental radiography service.

Keywords: patient satisfaction; quality of communication; the questionnaire; dental radiology

\section{PENDAHULUAN}

Layanan radiologi kedokteran gigi merupakan pelayanan kesehatan gigi yang sering digunakan sebagai pemeriksaan penunjang dalam menegak- kan diagnosis penyakit gigi dan mulut yang dilaksanakan dengan teknik pencitraan suatu objek menggunakan pemaparan radiasi sinar $\mathrm{X} .{ }^{1}$ Teknik pencitraan pada layananan radiologi mampu 
mendukung pekerjaan tenaga kesehatan gigi guna mengetahui keadaan sebelum dan sesudah perawatan. ${ }^{2}$ Layanan radiologi membutuhkan sumber daya manusia sebagai petugas radiografer untuk melaksanakan pelayanan. Petugas radiografer dituntut untuk memiliki pengetahuan dasar tentang komponen-komponen yang bekerja menghasilkan radiasi ionisasi pada pemaparan sinar $X$, bertanggung jawab terhadap dosis radiasi yang diterima oleh pasien, serta memiliki pengetahuan dan keterampilan untuk dapat menghasilkan radiograf yang berkualitas dan meningkatkan kepuasan pasien. ${ }^{3}$ Seorang radiografer juga harus memiliki komunikasi yang baik untuk dapat memposisikan pasien secara tepat, menempatkan film rontgen dengan benar, dan memberikan penjelasan mengenai bahaya paparan sinar $\mathrm{X}$ yang akan diterima pasien. ${ }^{4}$

Petugas layanan kesehatan seringkali mengabaikan tingkat kepuasan pengguna jasa layanan kesehatan, sehingga petugas radiografer sebagai petugas layanan kesehatan diharapkan mampu meningkatkan keterampilan dalam berkomunikasi dan memperhatikan tingkat kepuasan pasien melalui pelayanan yang diberikan. ${ }^{5}$ Petugas radiografer seringkali mengabaikan pengetahuan, empati, dan respon pasien dalam berkomunikasi. ${ }^{6}$ Enam perilaku yang dapat mempengaruhi kepuasan pasien terhadap komunikasi, antara lain nonverbal communication, do not act hurried, listen carefully, clear and simple explanation, shake, and introduce. ${ }^{7}$ Perhatian, kontak mata, bahasa tubuh, nada bicara, dan wajah merupakan hal penting yang dapat berpengaruh dalam meningkatkan respon emosional pasien karena pasien akan merasa dipedulikan oleh petugas layanan kesehatan. ${ }^{8}$

Kepuasan merupakan perasaan senang atau kecewa seseorang yang muncul setelah membandingkan kinerja hasil produk yang difikirkan terhadap hasil yang diharapkan. Kepuasan pasien adalah keadaan saat keinginan, harapan, dan kebutuhan pasien dapat terpenuhi. ${ }^{9}$ Pelayanan dinilai memuaskan jika memenuhi kebutuhan dan harapan pasien. ${ }^{10}$ Kepuasan pasien merupakan hasil yang menggambarkan keseluruhan faktor yang terlibat dalam memberikan pelayanan. Harapan pasien dari suatu pelayanan dan sikap petugas layanan kesehatan memiliki kontribusi yang baik terhadap kepuasan pasien. Faktor lain yang dapat mempengaruhi kepuasan pasien antara lain rasa sakit dan depresi yang dialami pasien. Komunikasi yang berkualitas juga merupakan faktor penting dalam meningkatkan kepuasan pasien terhadap layanan yang diterimanya. ${ }^{11}$ Komunikasi yang baik dapat menghasilkan hubungan yang baik antara petugas layanan kesehatan dengan pasien, mampu meningkatkan penilaian pasien terhadap petugas, dan meningkatkan kepuasan pasien terhadap layanan kesehatan. Kepuasan pasien dalam menilai komunikasi petugas layanan kesehatan merupakan hal penting yang sangat mendasar dari suatu pelayanan. ${ }^{7}$

Tujuan penelitian ini adalah untuk mengetahui hubungan antara tingkat kepuasan pasien terhadap kualitas komunikasi pada pelayanan radiografi kedokteran gigi di Rumah Sakit Gigi dan Mulut Prof. Soedomo. Kepuasan pasien merupakan hal penting yang harus diperhatikan dalam memberikan jasa pelayanan kesehatan. Kepuasan pasien merupakan alat ukur yang dapat digunakan untuk mengamati kualitas layanan kesehatan. Pengukuran tingkat kepuasan pasien dilakukan sejalan dengan sudut pandang pasien terhadap kualitas komunikasi petugas layanan kesehatan. ${ }^{12}$ Empat dimensi pengukur tingkat kepuasan pasien antara lain kemampuan petugas dalam mengawali dan mengakhiri pertemuan (open-endedness), empati petugas layanan kesehatan (empathy), kepercayaan pasien terhadap kemampuan petugas (abilities), dan kepuasan pasien terhadap interaksi yang terjadi dengan petugas (general satisfaction). ${ }^{13}$

\section{METODE PENELITIAN}

Penelitian ini merupakan penelitian observasional analitik dengan pendekatan cross sectional. Penelitian dilakukan di SMF Radiologi Dentomaksilofasial RSGM Prof. Soedomo Fakultas Kedokteran Gigi Universitas Gadjah Mada pada bulan Maret 2016. Keterangan laik etik (ethical clearance) pada penelitian ini diterbitkan oleh unit etik dan advokasi Fakultas Kedokteran Gigi UGM. Sampel penelitian sebanyak 100 responden diambil 
dari pasien yang melakukan pemeriksaan radiografi di SMF Radiologi Dentomaksilofasial RSGM Prof. Soedomo FKG UGM. Pemilihan sampel penelitian berdasarkan kriteria inklusi, antara lain pasien berusia $18-45$ tahun, pasien tidak buta huruf (mampu membaca dan menulis), pasien tidak dalam kondisi cacat fisik dan cacat mental, pasien mengerti bahasa Indonesia, pasien dengan tingkat pendidikan minimal SMA sederajat, dan pasien baru pertama kalinya melakukan pemeriksaan radiografi di SMF Radiologi Dentomaksilofasial RSGM Prof. Soedomo FKG UGM. Pengambilan sampel penelitian menggunakan teknik purposive sampling. Bahan penelitian yang digunakan berupa lembar kuesioner. Kuesioner pada penelitian terdiri dari kuesioner kualitas komunikasi terdiri dari 19 butir pertanyaan yang mencakup 4 aspek penilaian komunikasi (introduce, explanation, listen carefully, dan empathy) dan kuesioner tingkat kepuasan pasien terdiri dari 20 butir pertanyaan yang mencakup 4 aspek penilaian kepuasan pasien (open-endedness, empathy, abilities, dan general satisfaction).

\section{HASIL PENELITIAN}

Tabel 1 menunjukkan sebagian besar karakteristik responden pada penelitian ini berjenis kelamin perempuan (63\%) dengan tingkat pendidikan sebagian besar responden adalah lulusan SMA sederajat (72\%) dan rentang usia responden sebagian besar antara 18-26 tahun (85\%). Tabel 2 menunjukkan bahwa sebagian besar penilaian responden terhadap kualitas komunikasi pelayanan radiografi kedokteran gigi adalah baik dengan persentase sebesar $64 \%$. Gambar 1 menunjukkan distribusi jawaban responden terhadap aspek-aspek yang mempengaruhi kualitas komunikasi.

Tabel 3 menunjukkan bahwa sebagian besar responden (58\%) menyatakan aspek introduce yang diperlihatkan oleh radiografer memenuhi kriteria baik, $60 \%$ responden menyatakan aspek explanation memenuhi kriteria baik, $68 \%$ responden menyatakan aspek listen carefully memenuhi kriteria baik, dan $52 \%$ responden menyatakan aspek empathy yang

Tabel 1. Distribusi subjek penelitian berdasarkan usia, jenis kelamin, dan pendidikan

\begin{tabular}{|c|c|c|c|c|}
\hline No. & Variabel & Distribusi & $\mathbf{N}$ & $\%$ \\
\hline \multirow{3}{*}{1} & \multirow{3}{*}{ Usia } & $18-26$ tahun & 85 & 85 \\
\hline & & $27-35$ tahun & 9 & 9 \\
\hline & & $36-44$ tahun & 6 & 6 \\
\hline \multirow[t]{2}{*}{2} & \multirow[t]{2}{*}{ Jenis Kelamin } & Laki - laki & 37 & 37 \\
\hline & & Perempuan & 63 & 63 \\
\hline \multirow{3}{*}{3} & \multirow{3}{*}{ Pendidikan } & SMA sederajat & 72 & 72 \\
\hline & & D3 & 1 & 1 \\
\hline & & S1 & 27 & 27 \\
\hline
\end{tabular}

Keterangan: n: jumlah subjek dalam penelitian

Tabel 2. Penilaian responden terhadap kualitas komunikasi pelayanan radiografi kedokteran gigi RSGM Prof. Soedomo FKG UGM

\begin{tabular}{cccc}
\hline Kriteria & Rentang nilai & Jumlah responden & \\
& & 0 & 0 \\
\hline Sangat Tidak Baik & $1-19$ & 1 & 7 \\
Tidak Baik & $20-38$ & 64 & 7 \\
Kurang Baik & $39-57$ & 28 & 28 \\
Baik & $58-76$ & 100 & 100 \\
Sangat Baik & $77-95$ & & 28 \\
Total & & & \\
\hline
\end{tabular}


diperlihatkan oleh radiografer pada pelayanan radiografi kedokteran gigi berada dalam kriteria baik. Tabel 4 menunjukkan bahwa sebagian besar pasien radiografi kedokteran gigi RSGM Prof. Soedomo FKG UGM merasa puas terhadap pelayanan $(71 \%)$, sebesar $4 \%$ responden menyatakan perasaan kurang puas terhadap pelayanan, dan sisanya adalah sebesar $25 \%$ responden yang menyatakan perasaan sangat puas terhadap pelayanan radiografi kedokteran gigi RSGM Prof. Soedomo FKG UGM. Gambar 2 menunjukkan distribusi jawaban responden terhadap aspek-aspek yang mempengaruhi tingkat kepuasan pasien.
Tabel 5 menunjukkan bahwa sebagian besar responden (74\%) menyatakan aspek openendedness yang diperlihatkan oleh radiografer memenuhi kriteria puas, $71 \%$ responden menyatakan aspek empathy memenuhi kriteria puas, $74 \%$ responden menyatakan aspek abilities memenuhi kriteria puas, dan $72 \%$ responden menyatakan aspek general satisfaction memenuhi kriteria puas. Tabel 6 dan 7 menunjukkan bahwa kualitas komunikasi menunjukkan hubungan yang bermakna $(p<0,05)$ yang sangat kuat $(r=856)$ terhadap tingkat kepuasan pasien pada layanan radiografi kedokteran gigi. Nilai koefisien korelasi Spearman ( $r$ ) terhadap aspekaspek komunikasi dan aspek-aspek kepuasan dapat diamati pada Tabel 6 dan 7 .

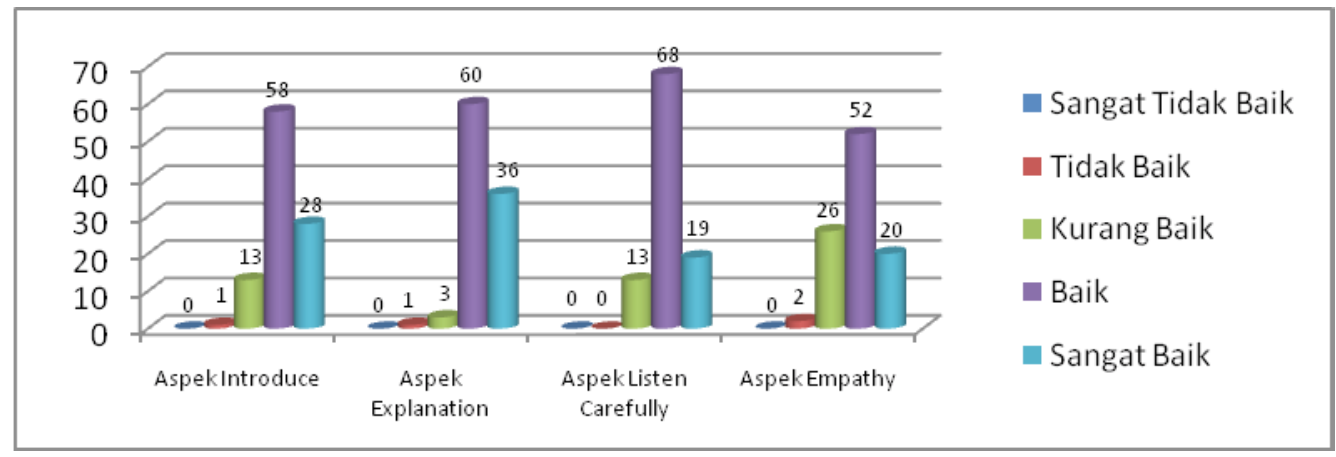

Gambar 1. Grafik distribusi jawaban responden terhadap aspek-aspek kualitas komunikasi

Tabel 3. Distribusi jawaban responden terhadap aspek-aspek kualitas komunikasi radiografer pada pelayanan radiografi kedokteran gigi

\begin{tabular}{ccccccccc}
\hline Kriteria & \multicolumn{2}{c}{ Aspek Introduce } & \multicolumn{2}{c}{ Aspek Explanation } & \multicolumn{2}{c}{ Aspek Listen Carefully } & \multicolumn{2}{c}{ Aspek Empathy } \\
& Nilai & $\%$ & nilai & $\%$ & nilai & $\%$ & nilai & $\%$ \\
\hline Sangat Tidak Baik & $1-5$ & 0 & $1-6$ & 0 & $1-4$ & 0 & $1-4$ & 0 \\
Tidak Baik & $6-10$ & 1 & $7-12$ & 1 & $5-8$ & 0 & $5-8$ & 2 \\
Kurang Baik & $11-15$ & 13 & $13-18$ & 3 & $9-12$ & 13 & $9-12$ & 26 \\
Baik & $16-20$ & 58 & $19-24$ & 60 & $13-16$ & 68 & $13-16$ & 52 \\
Sangat Baik & $21-25$ & 28 & $25-30$ & 36 & $17-20$ & 19 & $17-20$ & 20 \\
Total & & 100 & & 100 & & 100 & & 100 \\
\hline
\end{tabular}

Tabel 4. Penilaian responden terhadap tingkat kepuasan pasien radiografi kedokteran gigi RSGM Prof. Soedomo FKG UGM

\begin{tabular}{cccc}
\hline Kriteria & Rentang nilai & Jumlah responden & Persentase (\%) \\
\hline Sangat Tidak Puas & $1-20$ & 0 & 0 \\
Tidak Puas & $20-40$ & 0 & 0 \\
Kurang Puas & $41-60$ & 4 & 4 \\
Puas & $61-80$ & 71 & 71 \\
Sangat Puas & $81-100$ & 25 & 25 \\
Total & & 100 & 100 \\
\hline
\end{tabular}




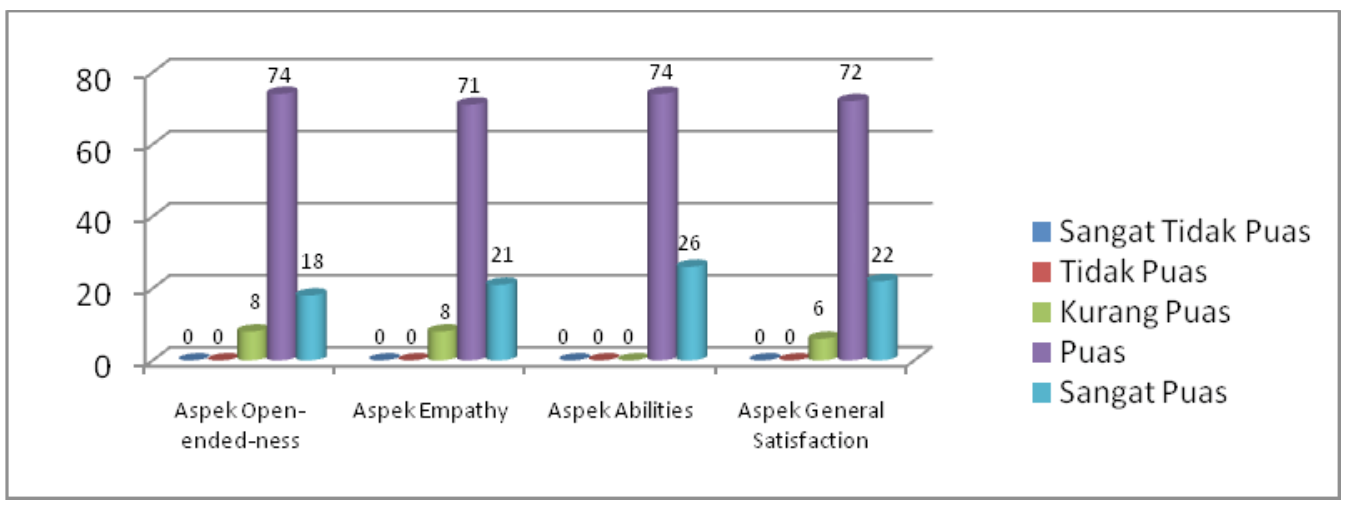

Gambar 2. Grafik distribusi jawaban responden terhadap aspek-aspek kepuasan pasien

Tabel 5. Distribusi jawaban responden terhadap aspek-aspek kepuasan pasien radiografer pada pelayanan radiografi kedokteran gigi

\begin{tabular}{ccccccccc}
\hline Kriteria & \multicolumn{2}{c}{$\begin{array}{c}\text { Aspek Open- } \\
\text { endedness }\end{array}$} & \multicolumn{2}{c}{ Aspek Empathy } & \multicolumn{2}{c}{ Aspek Abilities } & \multicolumn{3}{c}{$\begin{array}{c}\text { Aspek General } \\
\text { Satisfaction } \\
\end{array}$} & nilai & $\%$ & nilai & $\%$ & nilai & $\%$ & nilai & $\%$ \\
\hline Sangat Tidak Baik & $1-5$ & 0 & $1-9$ & 0 & $1-3$ & 0 & $1-3$ & 0 \\
Tidak Baik & $6-10$ & 0 & $10-18$ & 0 & $4-6$ & 0 & $4-6$ & 0 \\
Kurang Baik & $11-15$ & 8 & $19-27$ & 8 & $7-9$ & 0 & $7-9$ & 6 \\
Baik & $16-20$ & 74 & $28-36$ & 71 & $10-12$ & 74 & $10-12$ & 72 \\
Sangat Baik & $21-25$ & 18 & $37-45$ & 21 & $13-15$ & 26 & $13-15$ & 22 \\
Total & & 100 & & 100 & & 100 & & 100 \\
\hline
\end{tabular}

Tabel 6. Hasil korelasi spearman pada aspek penilaian kualitas komunikasi terhadap tingkat kepuasan pasien di RSGM Prof. Soedomo FKG UGM

\begin{tabular}{|c|c|c|}
\hline & $\begin{array}{c}\text { Correlation Coefficient } \\
\text { Kepuasan }\end{array}$ & Nilai $p$ \\
\hline Komunikasi & 0,856 & 0,000 \\
\hline Aspek Introduce & 0,752 & 0,000 \\
\hline Aspek Explanation & 0,680 & 0,000 \\
\hline Aspek Listen Carefully & 0,676 & 0,000 \\
\hline Aspek Empathy & 0,842 & 0,000 \\
\hline
\end{tabular}

Tabel 7. Hasil korelasi spearman pada aspek penilaian kepuasan pasien terhadap komunikasi di RSGM Prof. Soedomo FKG UGM

\begin{tabular}{lcc}
\hline & $\begin{array}{c}\text { Correlation Coefficient } \\
\text { Komunikasi }\end{array}$ & Nilai p \\
\hline \multicolumn{1}{c}{ Kepuasan } & 0,856 & 0,000 \\
Aspek Open-endedness & 0,676 & 0,000 \\
Aspek Empathy & 0,807 & 0,000 \\
Aspek Abilities & 0,433 & 0,000 \\
Aspek General Satisfaction & 0,706 & 0,000 \\
\hline
\end{tabular}

\section{PEMBAHASAN}

Karakteristik responden pada penelitian ini dideskripsikan menurut usia, jenis kelamin, dan tingkat pendidikan. Responden yang paling banyak menerima pelayanan radiografi kedokteran gigi
RSGM Prof. Soedomo FKG UGM adalah responden dengan kategori usia 18-26 tahun, berjenis kelamin perempuan, dengan tingkat pendidikan terakhir SMA sederajat. Hasil penelitian ini menunjukkan bahwa pemakai layanan radiografi kedokteran gigi RSGM Prof. Soedomo FKG UGM didominasi 
oleh kelompok usia dewasa muda berjenis kelamin perempuan dengan tingkat pendidikan SMA Sederajat. Jenis kelamin memiliki pengaruh terhadap tingkat kepuasan pasien, yaitu berupa cara pandang terhadap pelayanan yang diberikan. ${ }^{14}$ Perawatan gigi lebih banyak dilakukan oleh perempuan dari pada laki-laki karena perempuan lebih cenderung mementingkan kebersihan dan penampilan. ${ }^{15}$ Namun, Anjaryani menyatakan bahwa tidak terdapat hubungan antara jenis kelamin dengan tingkat kepuasan pasien terhadap suatu pelayanan. ${ }^{16}$ Sebagian besar responden penelitian termasuk dalam kategori usia dewasa muda dan memiliki tingkat pendidikan tinggi. Individu dengan usia dewasa muda dan tingkat pendidikan tinggi memiliki tingkat kesadaran yang lebih tinggi dalam menjaga dan merawat kesehatan gigi. ${ }^{17}$

Kualitas komunikasi radiografer pada pelayanan radiografi kedokteran gigi RSGM Prof. Soedomo FKG UGM dinilai baik oleh sebagian besar responden, yang mana penilaian kualitas komunikasi pada radiografer telah meliputi keempat aspek penilaian seperti aspek introduce, aspek explanation, aspek listen carefully, dan aspek empathy. Hasil ini menunjukkan bahwa aspek penilaian komunikasi masih perlu ditingkatkan oleh radiografer RSGM Prof.Soedomo FKG UGM guna meningkatkan kualitas komunikasi yang dimiliki. Kesan pertama yang diperlihatkan radiografer saat memberikan pelayanan radiografi kedokteran gigi RSGM Prof. Soedomo FKG UGM termasuk dalam kategori penilaian baik berdasarkan penilaian acuan patokan (PAP) oleh sebagian besar pasien, namun masih ada beberapa pasien yang memberikan penilaian buruk terhadap penerimaan awal radiografer. Hal tersebut kemungkinan dikarenakan oleh jumlah pasien yang berkunjung tidak seimbang dengan jumlah tenaga radiografer yang terlibat dalam pelayanan, sehingga beban layanan diduga mempengaruhi fokus radiografer dalam mempertahankan kualitas komunikasi yang hendak diberikan, antara lain radiografer lupa mengucapkan salam dan lupa memperkenalkan dirinya kepada pasien. Waktu tunggu atau respon waktu yang lama juga merupakan salah satu aspek penting dalam menentukan kepuasan pasien rawat jalan maupun di ruang rawat inap. ${ }^{15}$
Radiografer RSGM Prof. Soedomo FKG UGM telah memberikan instruksi dengan sopan, jelas, singkat dan mampu menanggapi pertanyaan pasien dengan baik. Supranto menyatakan bahwa ketanggapan seorang radiografer akan mempengaruhi kepuasan pasien setelah mendapatkan pelayanan jasa. ${ }^{18}$ Wira juga menyatakan bahwa sikap dan perilaku radiografer yang kurang komunikatif dapat menimbulkan ketidakpuasan pasien terhadap pelayanan yang diberikan. ${ }^{19}$ Hasil penelitian ini menyatakan bahwa radiografer telah memberikan kesempatan bertanya bagi pasien dan mendengarkan pertanyaan pasien dengan baik. Hasil ini sesuai dengan penelitian Hayden dkk. yang menyebutkan bahwa komunikasi yang baik dinilai melalui sikap radiografer saat mendengarkan dan merespon pasien. ${ }^{6}$

Permasalahan pelayanan terjadi pada waktu-waktu tertentu oleh karena tingginya jumlah kunjungan pasien di instalasi radiologi. Berdasarkan pengamatan penulis, kondisi tersebut dapat mempengaruhi sikap radiografer saat memberikan pelayanan. Petugas radiografer RSGM Prof. Soedomo telah menunjukan kualitas pelayanan yang baik, namun saat kunjungan pasien meningkat, terkadang radiografer menunjukkan tanggapan yang kurang baik saat berhadapan dengan pasien yang merasa ingin didahulukan. Mursyida menyatakan bahwa aspek empahty memiliki hubungan yang sangat bermakna terhadap tingkat kepuasan pasien. ${ }^{20}$ Kepuasan pasien akan tercapai jika diperoleh hasil pelayanan yang optimal bagi pasien yaitu pelayanan kesehatan yang memperhatikan setiap keluhan pasien. ${ }^{21}$

Tingkat kepuasan pasien pada pelayanan radiografi kedokteran gigi RSGM Prof. Soedomo FKG UGM dinilai sangat memuaskan oleh sebagian besar responden, yang mana penilaian tingkat kepuasan pasien terhadap petugas radiografer telah meliputi keempat aspek penilaian seperti aspek open-endednes, aspek empathy, aspek abilities, dan aspek general satisfaction. Hasil ini menunjukkan bahwa petugas radiografer layanan radiografi kedokteran gigi di RSGM Prof. Soedomo FKG UGM telah memberikan pelayanan yang memuaskan pasien dengan beberapa aspek penilaian kepuasan pasien yang masih perlu 
ditingkatkan. Hasil penilaian tersebut menyatakan bahwa radiografer mampu menciptakan suasana nyaman kepada sebagian besar responden yang berkunjung ke instalasi radiografi kedokteran gigi RSGM Prof. Soedomo FKG UGM. Hasil penelitian terhadap aspek empathy ini sejalan dengan penelitian Wira yang menyatakan bahwa sikap empati yang dimiliki oleh petugas radiografer dapat meningkatkan kepuasan pasien terhadap pelayanan radiografi. ${ }^{19}$ Radiografer dinilai terlihat handal saat mengoperasikan mesin sinar $X$ dan bersikap profesional saat memberikan instruksi kepada pasien sehingga sebagian besar pasien percaya terhadap kemampuan kerja radiografer. Muninjaya menyatakan bahwa petugas pelayanan kesehatan yang dapat diandalkan adalah petugas yang profesional dan mampu memberikan informasi yang tepat kepada pasien. ${ }^{22}$

Hasil uji korelasi Spearman pada penelitian ini menunjukkan nilai koefisien sebesar 0,856 dengan nilai signifikansi $(p)$ sebesar $0,000(p<$ $0,05)$. Hasil uji korelasi tersebut menjelaskan bahwa terdapat hubungan yang bermakna antara kualitas komunikasi pelayanan radiografi kedokteran gigi terhadap tingkat kepuasan pasien. Hubungan tersebut menunjukkan arah positif dengan kekuatan korelasi yang sangat kuat, sehingga semakin baik komunikasi yang diberikan oleh seorang radiografer maka semakin tinggi pula tingkat kepuasan pasien terhadap pelayanan radiografi kedokteran gigi.

Hasil uji korelasi spearman pada aspek-aspek penilaian kualitas komunikasi menunjukkan adanya hubungan yang signifikan $(p<0,05)$ dan kekuatan korelasi ( $r$ ) yang sangat kuat pada aspek empathy dibandingkan ketiga aspek penilaian kualitas komunikasi lainnya, sehingga apabila aspek empathy yang diperlihatkan radiografer semakin baik maka semakin tinggi pula tingkat kepuasan pasien, sama halnya dengan hasil uji korelasi spearman pada aspek-aspek penilaian kepuasan pasien menunjukkan adanya hubungan yang signifikan $(p<0,05)$ dan kekuatan korelasi $(r)$ yang sangat kuat pada aspek empathy dibandingkan ketiga aspek penilaian kepuasan pasien lainnya. Hal tersebut menunjukkan bahwa selain sangat berkaitan dengan kualitas komunikasi, aspek empathy juga merupakan aspek yang sangat berhubungan dengan kepuasan pasien.

Komunikasi yang baik dapat menghasilkan hubungan yang baik, mampu meningkatkan penilaian pasien terhadap petugas, dan meningkatkan kepuasan pasien terhadap layanan kesehatan. ${ }^{7}$ Berdasarkan hasil penelitian ini dapat disimpulkan bahwa terdapat hubungan bermakna $(p<0,05)$ yang sangat kuat antara tingkat kepuasan pasien dengan kualitas komunikasi pada pelayanan radiografi kedokteran gigi RSGM Prof. Soedomo FKG UGM. Hubungan tersebut menunjukkan arah positif dengan kekuatan korelasi yang sangat kuat $(r=0,856)$, sehingga semakin baik komunikasi yang diberikan oleh seorang radiografer, maka akan semakin tinggi pula tingkat kepuasan pasien terhadap pelayanan radiografi kedokteran gigi.

\section{KESIMPULAN}

Berdasarkan hasil penelitian ini dapat disimpulkan bahwa terdapat hubungan yang bermakna $(p<0,05)$ dengan korelasi positif yang kuat antara kualitas komunikasi dengan antara tingkat kepuasan pasien pada pelayanan radiografi kedokteran gigi RSGM Prof. Soedomo FKG UGM. Aspek komunikasi yang paling mempengaruhi kepuasan pasien adalah aspek emphaty. Semakin baik komunikasi yang digunakan radiografer maka akan semakin tinggi pula tingkat kepuasan pasien terhadap pelayanan radiografi kedokteran gigi RSGM Prof. Soedomo FKG UGM. Radiografer diharuskan memiliki kemampuan komunikasi yang baik agar meberikan pelayanan radiografi yang baik bagi pasien.

Penelitian ini tidak mengendalikan penilaian individual terhadap masing-masing petugas radiografer yang memberikan pelayanan, sehingga hasil penelitian ini tidak dapat digunakan untuk mengevaluasi setiap radiografer yang terlibat dalam pelayanan. Peneliti mengharapkan adanya penelitian lanjutan mengenai tingkat kepuasan pasien ditinjau dari hubungan dengan aspek selain komunikasi pada pelayanan radiografi kedokteran gigi. 


\section{DAFTAR PUSTAKA}

1. Whaites E. Essentials of dental radiography and radiology. United Kingdom: Churchill Livingstone; 2007. 157.

2. Wahyuningsih $S$, Hardjono $S$, Suparwitri $S$. Perawatan maloklusi angle klas I dengan gigi depan crowding berat dan cross bite menggunakan teknik begg pada pasien dengan kebersihan mulut buruk. Majalah Kedokteran Gigi. 2014; 21(2): 204 - 211.

3. White SC, Pharoah MJ. Oral radiology principles and interpretation. $7^{\text {th }}$ ed. Canada: Elsevier Mosby; 2009. 146

4. Thomson E, Johnson O. Essentials of dental radiography. $9^{\text {th }}$ ed. USA: Pearson New International Edition; 2014. 145 - 150.

5. Raz $A E$, Fadlon J. We came to talk with people behind the disease: communication and control in medical education. Cult Med Psychiatry. 2006; 30(1): $55-75$.

6. Hayden AC, Pichert JW, Fawcett J, Moore IN, Hickson GB. Best practice for basic and advanced skill in health care service recovery: a case study of a re-admitted patient. Jt Comm J Qual Patient Saf. 2010; 36(7): 310 - 8.

7. Quigley DD, Eliott MN, Farley DA, Burkhart Q, Skootsky SA, Hays RD. Specialties differ in which aspect of doctor communication predict overall physician ratings. J Gen Intern Med. 2013; 29(3): 447 - 454.

8. Marschner L, Pannasch S, Schulz J, Graupner ST. Social communication with virtual agents: the effects of body and gaze directions on attention and emotional responding in human observers. Int'l Journal of Psychosocial Rehab. 2015; 97(2): 85 - 92.

9. Kotler P, Kevin LK. Manajemen pemasaran. $12^{\text {th }}$ ed. St. Louis: Index; 2008. 161.

10. Pohan I. Jaminan mutu layanan kesehatan. Jakarta: EGC; 2006. 48.

11. Brent MJ, Alex A, Jahangir MD, Manish KS. Patient satisfaction: an emerging health policy issue. J Am Acad Orthop Surg. 2013; 7(6): 29.
12. Otani K, Waterman B, Faulkner KM, Boslaugh $S$, Burroughs TE, Dunagan WC. Patient satisfaction: focusing on excellent. Int $\mathrm{J}$ Healthc Manag. 2009; 54: 93 - 103.

13. Grayson K, Dwamena FC, Smith S, Laird $\mathrm{H}$, Freilich L, Smith RC. A questionnaire identifying four key components of patient satisfaction with physician communication: patient education and counseling. 2016; 99(6): 1053 - 1061.

14. Gunarsa S. Psikologi perawatan. Jakarta: Gunung Mulia; 2008. 90.

15. Pohan IS. Jaminan mutu layanan kesehatan: dasar-dasar pengertian dan penerapan. Jakarta: EGC; 2007. 45.

16. Anjaryani WD. Kepuasan pasien rawat inap terhadap pelayanan perawat di RSUD Tugu Rejo Semarang [internet]. 2009 [cited 2016 May 02]. Available from Netlibrary: http// eprints.undip.ac.id.

17. Notoatmodjo S. Metodologi penelitian kesehatan. Jakarta: PT Rineka Cipta; 2010. 78.

18. Supranto J. Pengukuran tingkat kepuasan untuk menaikkan pangsa pasar. Jakarta: PT. Rineka Cipta; 2011. 34.

19. Wira D, Suarjana WG. Hubungan antara persepsi daya tanggap dan persepasi empati dengan kepuasan pasien di RSUD Wangaya Denpasar. J Prev Med Public Health. 2014; 2(2): $150-155$.

20. Mursyida RF, Mawarni A, Agushybana F. Kepuasan ibu hamil dan persepsi kualitas pelayanan antenatal care di puskesmas tanjung kabupaten sampang madura. Media Kesehatan Masyarakat Indonesia. 2012; 11(2): $174-181$.

21. Kotler P. Manajemen pemasaran: analisis perencanaan implementasi dan kontrol. $12^{\text {th }}$ ed. Jakarta: PT. INDEKS; 2007. 56.

22. Muninjaya G. Manajemen mutu pelayanan kesehatan. $3^{\text {th }}$ ed. Jakarta: Penerbit Buku Kedokteran; 2011. 121 - 130. 